\title{
DNA carryover in milk samples from routine milk recording used for PCR-based diagnosis of bovine Staphylococcus aureus mastitis
}

\author{
Yasser S. Mahmmod, ${ }^{*}{ }^{1}$ Ilka C. Klaas, ${ }^{*}$ and Carsten Enevoldsen* \\ ${ }^{*}$ Department of Veterinary and Animal Sciences, Faculty of Health and Medical Sciences, University of Copenhagen, \\ DK-1870 Frederiksberg C, Denmark \\ †Infectious Diseases, Department of Animal Medicine, Faculty of Veterinary Medicine, Zagazig University, Zagazig City 44511, \\ Sharkia Province, Egypt
}

\begin{abstract}
Real-time PCR techniques are increasingly used to detect udder pathogens from milk samples collected non-aseptically at routine milk recording. The objectives of this study were (1) to estimate the statistical associations between cycle threshold (Ct) values for Staphylococcus aureus in non-aseptically collected composite samples taken at routine milk recording from cows milked consecutively with the same milking unit and milk meter; and (2) to formulate practical and plausible guidelines for understanding the diagnostic implications of PCR testing for Staph. aureus intramammary infection at routine milk recording. The study included 4 herds with conventional milking parlors and repeatedly low Ct-values for Staph. aureus (representing a high DNA load) in bulk tank milk. Composite milk samples were collected from all cows at all milking units during routine milk recording using the Tru-Test electronic milk meter (Tru-Test Group, Auckland, New Zealand) and analyzed using the PathoProof PCR (Thermo Fisher Scientific, Vantaa, Finland) assay. Milking clock times were retrieved at each milk meter to establish the milking order of the cows at each unit. A multinomial logistic regression was applied to estimate the association between $\mathrm{Ct}$-values from cows milked consecutively with the same milking unit and milk meter. The following groups were selected based on Ct-values: (1) 0-31.3, (2) 31.4-33.9, (3) 34.0-37, (4) 37.1-39.9, and (5) 40 (negative result). The association between groups from cows milked consecutively with the same milking unit and milk meter was statistically significant. Approximately $60 \%$ of cows were in $\mathrm{Ct}$ group 5 if the antecedent cow was also in Ct group 5, but only $20 \%$ of cows were in Ct group 5 if the antecedent cow was in $\mathrm{Ct}$ group 1. The probability of cows
\end{abstract}

Received November 18, 2016.

Accepted March 25, 2017.

${ }^{1}$ Corresponding author: yasserpcr@gmail.com being in Ct group 1 was not markedly influenced by the group of the antecedent cow. Statistical relationships in the intermediate range gave a plausible indication of a dose-response relationship. Carryover of bacterial DNA via the milking unit and milk meter is very likely to affect PCR results for Staph. aureus. Therefore, information about milking order must be considered in mastitis control efforts. We suggest a practical interpretation of PCR results: cows with a Ct-value $<32$ can be labeled "very likely to be infected with Staph. aureus," but cows with Ct-values of $>37$ and 32-37 can be labeled "very likely to be negative for Staph. aureus" and "uncertain Staph. aureus status," respectively.

Key words: DNA carryover, milking order, test misclassification, PathoProof PCR assay, Staphylococcus aureus

\section{INTRODUCTION}

Staphylococcus aureus is one of the most important udder pathogens, causing major economic losses worldwide (Barkema et al., 2006; Dufour et al., 2012; Boss et al., 2016). In 2012, 91\% of the bulk tank milk samples from all 4,258 Danish dairy herds were positive for Staph. aureus according to PCR analysis (Katholm et al., 2012). Sørensen et al. (2010) reported an economic loss of $€ 570$ per case of Staph. aureus mastitis, considerably higher than the economic losses caused by other mastitis pathogens. The infected udder represents a major reservoir for Staph. aureus; spread of the pathogen occurs during milking from contaminated teat cup liners, milking equipment, and the milker's hands (Keefe, 2012). Reducing the spread of Staph. aureus between dairy cows is vital for profitable udder health management. Early and accurate detection of Staph. aureus IMI is important for improving control programs and preventing the spread of infection among cows.

Since 2010, Danish farmers have been able to order cow-level PCR tests (PathoProof Mastitis PCR assay; Thermo Fisher Scientific, Vantaa, Finland) as part of 
routine milk recording for herd improvement using nonaseptically collected composite samples (Katholm et al., 2012). The results of the PCR assay are expressed as cycle threshold (Ct) values, which represent the number of PCR cycles (maximum 40) required to reach a predefined threshold fluorescence signal level. The higher the amount of bacterial DNA present in the milk sample, the lower the Ct-value (Koskinen et al., 2008). Several studies have shown that the assay has a higher sensitivity and specificity for Staph. aureus and Streptococcus agalactiae than bacteriological culture (Cederlöf et al., 2012; Mahmmod et al., 2013a). However, these results were based on non-aseptically collected samples and may have been prone to a risk of false positive results because of microbial teat colonization, contamination of teat orifices and teat skin with bacterial cells (Larsen et al., 2000; Zecconi, 2006), or carryover of bacterial DNA from the milking cluster, hoses, milk meters, or samplers (Britten, 2012; Sievert and Cantin, 2014). As well, teat disinfection and discarding the first streaks of milk before taking composite samples decreased the odds of a positive Staph. aureus test at a Ct-value cutoff of $\leq 37$ (Mahmmod et al., 2013b), indicating that contamination of samples from colonized teat skin and teat canals does occur and can cause false positive results.

Carryover of a small amount of milk from one cow sample to the next is possible because of residual milk in the milking unit, milk meter, or milk sampler (Løvendahl and Bjerring, 2006; Kelton and Godkin, 2014). Previous studies have estimated the carryover based on milk components such as fat, protein, and SCC, and even on dye tracer in an experimental setup (Friggens and Rasmussen, 2002; Løvendahl and Bjerring, 2006; Byrem et al., 2013). Based on Strep. agalactiae DNA Mahmmod et al. (2014) estimated milk carryover and found that the correlation between consecutively milked cows was 13,11 , and $9 \%$ at Ct-value cutoffs of $<40$, $\leq 37$, and $\leq 34$, respectively. Nevertheless, information is lacking about the level and variation of carryover contamination in detecting Staph. aureus IMI at routine sample collection. Nekouei et al. (2015) reported that carryover of antibodies or other diagnostic targets (e.g., DNA) could complicate interpretation of the diagnostic test results for diseases when samples from shared milk meters are used. Carryover could bias the diagnosis of Staph. aureus IMI with PCR tests and samples from routine milk recording, leading to overestimation of the prevalence of infected cows and excessive use of antibiotics in treating false positive cows. Estimates of the likelihood of Staph. aureus positive test results at several PCR Ct-value cutoffs is essential for detecting sources of false-positive PCR results and reducing misclassification of Staph. aureus status and avoiding misdiagnosis.

In herds that do not segregate cows according to infection status, we can assume that milking units are randomly allocated. Consequently, if carryover does not exist, a systematic statistical association based on the PCR Ct-values of cows milked consecutively is very unlikely. If carryover does exist, we would expect to observe consistently low Ct-values (an indication of Staph. aureus infection) among cows milked after a cow with a low Ct-value. Consequently, the number of positive test results should be related to the choice of Ct-value cutoff (Mahmmod et al., 2014), comparable to a dose-response effect, which provides strong evidence of causation. The objectives of this multi-herd observational field study with natural randomization were (1) to estimate the statistical associations between the Ct-values of cow-level PCR tests for Staph. aureus in non-aseptically collected composite samples taken at routine milk recording from cows milked consecutively with the same milk meter and milking unit; and (2) to formulate practical and plausible guidelines for understanding the diagnostic implications of PCR testing for Staph. aureus IMI at routine milk recording. In contrast to previous studies, we studied multiple categories of PCR in the same model (multinomial logistic regression) to detect possible dose-response effects of carryover during milking.

\section{MATERIALS AND METHODS}

\section{Study Population}

We selected 4 Danish dairy herds with conventional milking parlors and repeatedly low Ct-values for Staph. aureus in the bulk tank milk. These herds were a subset of 6 herds described by Mahmmod et al. (2013a,b), for which complete information about milking order during milk recording was available. Table 1 shows information about the herd size, the number of samples taken per herd, the type of milking system, and PCR Ct-values from bulk tank milk for Staph. aureus.

\section{Data Collection}

Sample collection was carried out as described in Mahmmod et al. (2013a,b). Composite milk samples for PCR testing were automatically collected from all lactating dairy cows after the farm personnel had carried out their routine pre-milking practices. The milk samples were collected at routine milk recording between March 28 and May 28, 2011, using the Tru-Test electronic milk meter (Tru-Test Group, Auckland, New 
Table 1. Study population, including number of lactating dairy cows examined by real-time PCR, number of milk meters per herd, type of milking parlor, and cycle threshold (Ct) values of bulk tank milk (BTM) PCR testing in 4 Danish dairy herds for Staphylococcus aureus (SA)

\begin{tabular}{llccccc}
\hline & & & & \multicolumn{2}{c}{ Ct-value of BTM PCR testing for SA } \\
\cline { 5 - 7 } Herd code & Milking parlor type & Cows (no.) & $\begin{array}{c}\text { Cows tested } \\
\text { by PCR (no.) }\end{array}$ & $\begin{array}{c}\text { Milk } \\
\text { meters (no.) }\end{array}$ & October 2010 & March 2011 \\
\hline H1 & Herringbone & 148 & 127 & 16 & 34 & 31 \\
H2 & Herringbone & 319 & 317 & 28 & 35 & 31 \\
H3 & Side by side & 194 & 193 & 32 & 31 & 32 \\
H4 & Herringbone & 161 & 157 & 101 & & \\
Total & & 822 & 794 & & \\
\hline
\end{tabular}

Zealand). The bronopol-preserved milk samples were delivered to Eurofins Steins Laboratory (Holstebro, Denmark) within $24 \mathrm{~h}$ of collection and analyzed using the PathoProof Mastitis PCR assay (Thermo Fisher Scientific).

We screened the data for obviously erroneous or missing values and excluded no data on this basis. Data on parity, SCC, DIM, and daily milk yield were extracted from the Danish Cattle Database (Lind et al., 2012; https://www.seges.dk/) and merged with the PCR results for Staph. aureus. Data from the milk meters included milk meter identification number, cow identification number, milk yield and milking start and end times for each cow at each meter. Data obtained from the milk meters were used to identify the milking order of cows for each milking unit.

\section{Statistical Analysis}

Several cutoff values for PCR have been suggested by the manufacturer and by researchers applying the diagnostic method (PathoProof Mastitis PCR assays, Thermo Fisher Scientific Inc.; Koskinen et al., 2009, 2010; Cederlöf et al., 2012). In the absence of a coherent theory that would allow us to choose a single cutoff to correctly identify the true status of a cow with Staph. aureus IMI, we applied a multinomial logistic regression model for statistical analysis. This model allowed us to specify several cutoff values without assuming proportionality between each level of the outcome variable and of the explanatory variable of interest (we used generalized logits). We chose the following 5 categories (Ct groups) for the PCR Ct-values: 0-31.3 (group 1), 31.4-33.9 (group 2), 34.0-37 (group 3), 37.1-39.9 (group 4), and 40 (group 5). The categories represented a compromise between the distribution of $\mathrm{Ct}$-values in our data, the goal of retaining as much information as possible, and the possibility of examining previously applied Ct-values cutoff. Multinomial logistic regression also allowed us to estimate the relationship between the PCR category for each cow and all possible categories for the cows being milked with the same milk meter immediately beforehand (a so-called lag effect). Given the plausibility of random exposure to Staph. aureus, this approach enabled us to estimate the probability of carryover via the milking order among cows milked at the same milking unit and interpret the statistical associations as causal effects.

The outcome variable was the $\mathrm{Ct}$ group (1 to 5 ). The explanatory variable of primary interest was the Ct group of the antecedent cow (PriorCt). Maximum likelihood estimation was applied. Herd identity was included in the model as a fixed effect to account for possible general herd effects. The effect of interaction between herd and PriorCt was tested to judge whether the possible effects of PriorCt were heterogeneous across herds. Possible effects of the available cow-level information were explored; SCC (log-transformed) and duration of milking were retained, together with PriorCt and herd (Table 2). Other available factors related to the cows and the milking process were not statistically significant. The analysis was performed using

Table 2. Descriptive statistics for a subset of variables included in the analysis to estimate the risk of carryover in real-time PCR used to diagnose Staphylococcus aureus IMI from 794 dairy cows at routine milk recording

\begin{tabular}{|c|c|c|c|c|}
\hline Variable & Mean & Minimum & Median & Maximum \\
\hline PCR cycle threshold value for Staph. aureus & 38 & 23 & 40 & 40 \\
\hline $\mathrm{SCC}\left(\times 10^{3}\right.$ cells $\left./ \mathrm{mL}\right)$ & 329 & 3 & 88 & 9,999 \\
\hline Total milk yield ( $\mathrm{kg} / \mathrm{d})$ & 30 & 4 & 30 & 76 \\
\hline Parity & 2 & 1 & 2 & 7 \\
\hline DIM & 203 & 7 & 193 & 924 \\
\hline Log-transformed SCC & 5 & 1 & 5 & 9 \\
\hline Milking duration (s) & 355 & 3 & 325 & 1,635 \\
\hline
\end{tabular}


Table 3. Frequency distribution of PCR cycle threshold (Ct) value groups of 794 lactating dairy cows and statistically significant risk factors retained for estimation of the risk of DNA carryover on real-time PCR to diagnose Staphylococcus aureus IMI based on composite milk samples (non-aseptically collected) at routine milk recordings

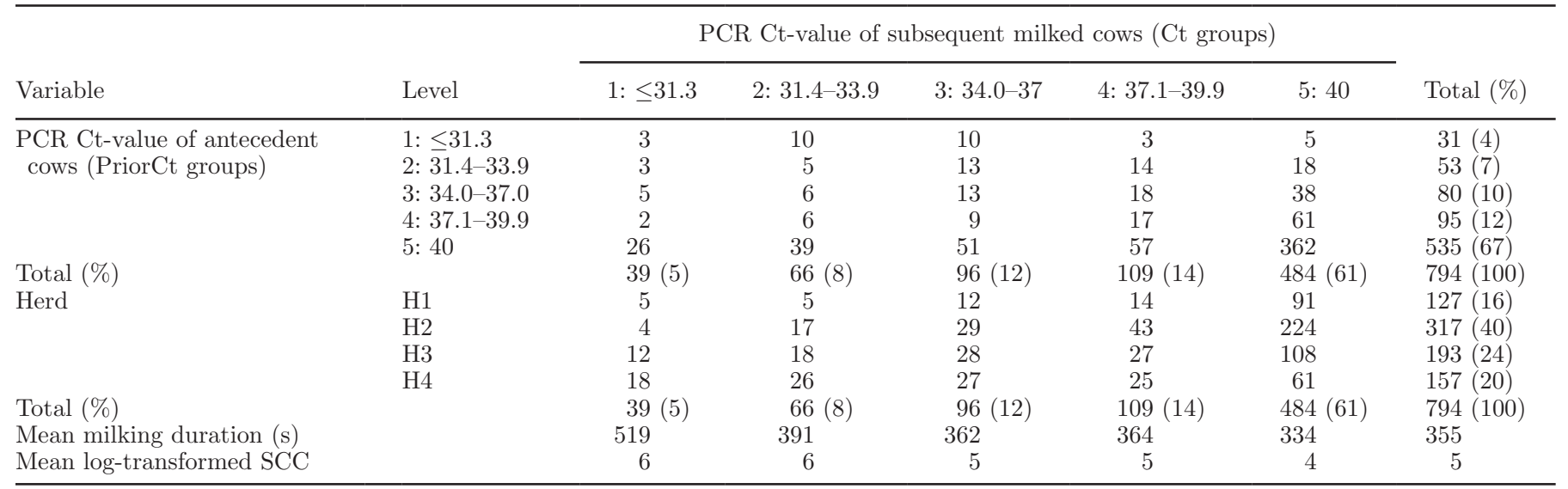

PROC LOGISTIC in SAS software (version 9.4; SAS Institute Inc., Cary, NC).

\section{RESULTS}

A total of 822 cows from the 4 herds were selected for PCR testing, and 28 of these were excluded because they were dry. The analysis included 794 cows with complete data from 101 milk meters. When a cow was milked first with a milking unit, the Ct-value for the variable PriorCt was set to 40 in the model. Tables 2 and 3 show descriptive statistics for the dependent and independent variables. Routine milking practices were similar in the 4 herds, including teat cleaning with individual boiled towels, and no pre-milking teat dips. All herds applied a post-milking teat dip. None of the herds segregated infected cows or milked non-infected or first-lactation cows first to prevent new infections during the study period (no specific milking order).

Figure 1 shows the distribution of cows in the selected $\mathrm{Ct}$ groups and the statistical relationships between PriorCt groups and subsequent $\mathrm{Ct}$ categories (including 95\% CI at each cutoff point estimated using the multinomial logistic regression model). The statistical significance of the overall relationships between the multinomial (unordered categories) Ct group and PriorCt was very strong $(P<0.0001)$. The herd effect was statistically important $(P=0.01)$, but the statistical significance of the interaction between herd and PriorCt was negligible $(P>0.5$, likelihood ratio test). That is, we could not detect substantial evidence of heterogeneity due to herd in the patterns of slopes in Figure 1 across herds. The $P$-value produced by the score test for proportional odds assumption was $<0.0001$, showing that a proportional odds assumption (a simpler and more restrictive model) clearly would be invalid.

The proportion of cows in PriorCt group 1 was $4 \%$ (Table 3). The point estimates of probabilities in PriorCt group 1 for the occurrence of the $5 \mathrm{Ct}$ groups among the subsequently milked cows varied between a little less than $40 \%$ and around 10\% (wide confidence intervals). The proportions of cows in PriorCt groups 5 (Ct-value 40) and 4 (Ct group 37.1-39.9) were 67 and $12 \%$, respectively (Table 3 ). The point estimates of the probability of occurrence of Ct group 5 among cows milked after PriorCt groups 4 and 5 were similar at around $60 \%$, about 3 times higher than among cows in PriorCt group 1 (Table 3). Remarkably, the point estimates of the probability of occurrence of $\mathrm{Ct}$ group 5 among cows milked after PriorCt groups 1 and 4 (the range of Ct-values from minimum to 37) increased almost linearly from below 20 to around 60 , indicating a dose-response relationship. The point estimates of the probability of occurrence of $\mathrm{Ct}$ groups 1 to 4 among cows milked after PriorCt group 5 were statistically indistinguishable and about $10 \%$ each. The line trajectories (curves) from $\mathrm{Ct}$ groups 1 to 4 indicated a steady decrease in variability from PriorCt groups 1 to 5, which can be interpreted as less (rather unpredictable) carryover. The low $P$-value for the proportional odds assumption was reflected visually by the heterogeneous trajectories in Figure 1, confirming that a proportional odds assumption would be an invalid approach.

\section{DISCUSSION}

To the best of our knowledge, this is the first reported field study using PCR to investigate possible Staph. aureus carryover between consecutive composite 
milk samples from routine milk recording. Our study design and the very strong statistical associations we observed allow us to conclude that a causal relation exists between the Staph. aureus status in the milk of a given cow and the Staph. aureus status in the milk of a cow milked subsequently with the same milking unit/milk meter (higher risk with increasing Staph. aureus exposure). Consequently, carryover via the milking unit/milk meter can affect the PCR results for Staph. aureus considerably. Our findings demonstrate that carryover can falsely modulate the cutoff estimate response profile of PCR Ct-values from subsequently milked cows. The degree of modulation relies on the degree of carryover, shown in Figure 1 by the Ct-value of the antecedent cow milked with the same milk meter. Therefore, the effect of carryover may interfere with accurately identifying the true status of Staph. aureus IMI in dairy cows milked at routine milk recording.

Our findings are supported by previous laboratory experiments (Koskinen et al., 2008, 2009) and field studies (Taponen et al., 2009; Koskinen et al., 2010; Cederlöf et al., 2012), which concluded that different PCR Ct-value cutoffs reflect different DNA concentrations of Staph. aureus (bacterial load). Therefore, the use of different PCR Ct-value cutoffs to classify a cow as infected will lead to different interpretations of test results. Hiitiö et al. (2016) concluded that lowering the Ct-value cutoff would decrease the number of samples classified as positive for udder pathogens. Hence, the positive Staph. aureus PCR result was expected to be different at high Ct-value cutoffs than at low cutoffs, but the underlying degree of carryover of DNA from cow to cow through the milking system would remain unchanged.

Our results demonstrated that DNA carryover occurs when using non-aseptically collected milk samples for PCR analysis at routine milk recording, reducing the accuracy of Staph. aureus IMI diagnosis. This finding is consistent with the conclusion of Friendship et al. (2010) that identifying Staph. aureus IMI based on PCR

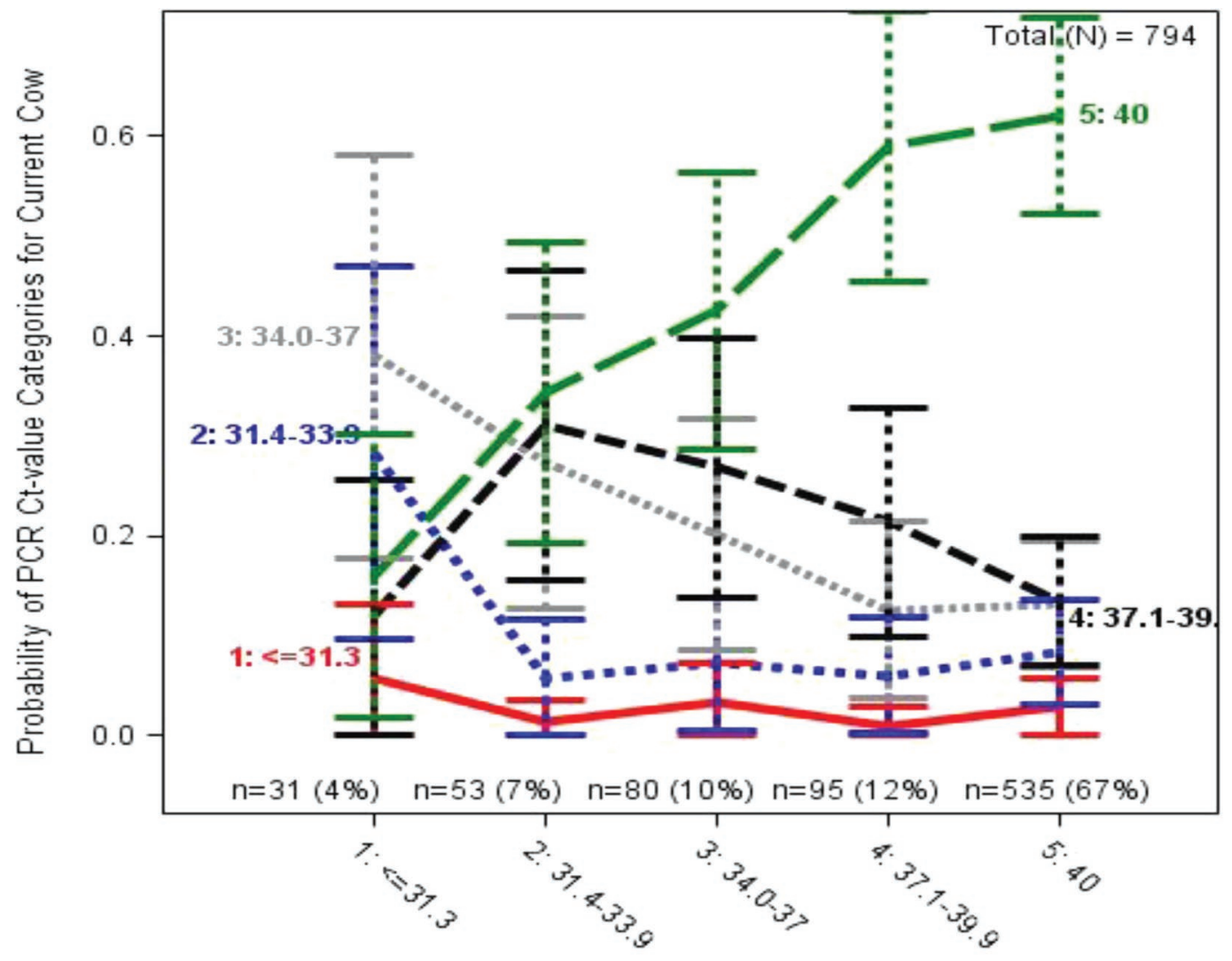

PCR Ct-value Antecedent Cow in Milk Meter

Figure 1. Relationships between PCR cycle threshold (Ct) values of Staphylococcus aureus at the current milking (y-axis) and the Ct-values from the antecedent cow (5 categories on the x-axis) milked with the same milk meter. The predictions (point estimates with $95 \% \mathrm{CI}$ ) from the final multinomial logistic regression model are adjusted for herd $(P=0.012)$, log-transformed SCC (quadratic; $P<0.0002)$, and duration of milking $(P<0.0003)$. Other available factors related to the cows and milking process were not statistically significant. Data were collected from 794 cows in 4 Danish dairy herds. Color version available online. 
using non-aseptic milk samples may reveal a certain degree of carryover. Mahmmod et al. (2014) reported a similar finding for Strep. agalactiae. The findings of the present study, together with those of previous studies, demonstrate that interpreting the results of DNA-based diagnostics, without considering the milking order or other mastitis indicators, should be very circumspect.

No guidelines or recommendations for interpreting PCR test results to identify udder pathogens are available in the literature, to the best of our knowledge. In Ireland, Keane et al. (2013) reported that the use of PCR technology might assist in rapid mastitis diagnosis, but accurate interpretation of PCR results in the absence of bacterial culture remains problematic. Hiitiö et al. (2015) proposed that the concept of contaminated samples should also be considered for PCR assays used in routine bovine mastitis diagnostics. In agreement with Hiitiö et al. (2016) and Steele et al. (2015), we recommend that results from any microbiological analysis should always be interpreted with all available information - such as clinical signs and history, and milk SCC - when making decisions about antimicrobial treatment or other control measures. We also recommend including the milking order and information about the PCR Ct-value of the antecedent cow in the decision-making process.

The heterogeneous curves observed for the 5 different Ct-value categories indicate a lack of proportionality, so choosing a single cutoff (dichotomization) may lead to loss of potentially important information. The overall pattern in Figure 1 indicated that we needed at least 3 categories, and the following appear to be plausible for classifying samples taken automatically at DHI and tested with a PCR assay: (A) very likely to be infected with Staph. aureus (Ct-values $<32)$; (B) very likely to be negative for Staph. aureus (Ct-values $>37$ ); and (C) uncertain Staph. aureus status (Ct-values between 32 and 37).

Cows in category A with a Ct-value $<31.4$ (Ct group 1) are most likely to shed so many DNA copies that the DNA from the previously milked cow does not make a real difference or change their true status. The risk of observing this category was about the same, irrespective of the Ct-value group of the antecedent cow. In spiked samples, Koskinen et al. (2008) found a linear relationship on the $\log$ scale and that a Ct-value of 30 was equivalent to $500,000 \mathrm{cfu} / \mathrm{mL}$ of Staph. aureus, but that a Ct-value of 27 was equivalent to 5,000,000 $\mathrm{cfu} / \mathrm{mL}$. From clinical mastitis samples, Taponen et al. (2009) reported that Ct-values of 28.4 and 31.7 were equivalent to $5.3 \times 10^{6}$ and $6.2 \times 10^{5}$ genome copies of Staph. aureus per $\mathrm{mL}$ of milk, respectively. This association can also be expected (at least to some extent) for naturally infected cows in the present study, although studies investigating the association between counts in colony-forming units per milliliter and Ctvalues from natural infections with Staph. aureus are sparse. The larger number of DNA copies corresponding to Ct-values $<32$ are unlikely to be achieved alone by contamination, carryover, or both, and may therefore indicate a truly infected cow. Consequently, dairy health advisors do not need to require other procedures (e.g., retesting) to confirm the status of a cow in $\mathrm{Ct}$ group 1. Cows in this category can be an important source of contamination of the milk sample from the subsequently milked cow at the same milk unit/meter through carryover effect.

Category C (uncertain Staph. aureus status) can also be called "borderline." Access to information about the Ct-value of the previously milked cow could be very useful for evaluation of possible carryover effects. Koskinen et al. (2008) found that from Ct-values 33 to 35, the corresponding amount of Staph. aureus drops from approximately 5,000 to $500 \mathrm{cfu} / \mathrm{mL}$ in spiked milk samples. Meanwhile, Taponen et al. (2009) reported that a Ct-value of 34.5 was equivalent to $9.4 \times 10^{4}$ genome copies of Staph. aureus per $\mathrm{mL}$ of clinical mastitis milk samples. In non-aseptically collected samples at routine milk recording, Cederlöf et al. (2012) and Mahmmod et al. (2014) observed similar sensitivity for bacterial culture and PCR at the lowest chosen Ctvalue cutoff of 34 . This could indicate that a cutoff of 34 is close to the bacteriological culture detection thresholds of $100 \mathrm{cfu} / \mathrm{mL}$ (Cederlöf et al., 2012) or 200 $\mathrm{cfu} / \mathrm{mL}$ (Mahmmod et al., 2014). The considerably lower cfu number compared with $\mathrm{Ct}$ group 1 may be easily affected by the carryover effect, and it would be difficult to ensure the true IMI status of the cow based on Ct-value alone. To make conclusions about the IMI status of cows in this category, further diagnostic testing would be needed (e.g., SCC or culture), or a new aseptically collected milk sample for PCR testing.

Category B (very likely to be negative for Staph. aureus) cows are most "vulnerable" to being misclassified as positive if they are milked after a cow in Ct group $1,2,3$, or (maybe) 4. The bacterial DNA concentration of Staph. aureus would be expected to be low at higher Ct-values and minor carryover may easily affect or modulate the Ct-value for cows milked subsequently using the same milk meter. Nekouei et al. (2015) have reported a similar finding for the diagnosis of bovine leukemia virus based on the ELISA. The authors concluded that carryover of bovine leukemia virus antibodies at shared milk meters was significant. For ELISA low-titer cows (i.e., true negatives), the likelihood of bovine leukemia virus antibody carryover significantly increased as the titer of preceding cows increased, but this change was not substantial for high-titer cows. 
It is very difficult to avoid carryover during test sampling at routine milk recordings for many reasons, including high costs or interference with test results. These issues have been thoroughly described by Nekouei et al. (2015) and Walsh et al. (2013) for the detection of leucosis.

Many sources exist for carryover during sample collection, such as milking cluster, hoses, milk meter, flask, or sampler, as suggested by Sievert and Cantin (2014). They stated that a device and sampler could have 3 $\mathrm{mL}$ of milk from the previous cow in the sampler tube or hose. Therefore, the degree of carryover of Staph. aureus from one cow to another may be affected by factors such as the type of milking system (automatic vs. conventional), the type and model of the milk meter, the type of Tru-Test device, and the size of the sampler. The milk yield of cows could also be of importance, but was not statistically significant in our study (results not shown). Based on the milk components, a carryover degree of $<5 \%$ was reported for conventional milking systems, but this degree was higher in automatic milking systems (up to 20\%) (Løvendahl and Bjerring, 2006; Løvendahl et al., 2010). Those studies showed that carryover is a complicated issue and a true challenge for mastitis diagnostics when milk samples are taken non-aseptically using automatic sampling during milk recording. If not considered properly, carryover effects may result in considerable economic expenses/losses as a result of unjustified culling, unnecessary treatment, overestimation of IMI prevalence, and repeated testing.

The findings of this study provide a very plausible interpretation of the diagnostic implications of PCR testing for Staph. aureus IMI in dairy herds at routine milk recording, and we hope it will facilitate the interpretation of PCR Ct-values for dairy advisors to accurately diagnose Staph. aureus IMI under field conditions and to improve udder health. However, future studies may be necessary to establish more accurate guidelines for the type, source, and definition of contamination of milk samples collected for mastitis diagnostics based on PCR assays at routine milk recording to avoid misidentification of IMI and misinterpretation of the results.

\section{CONCLUSIONS}

A causal relation exists between the Staph. aureus load in the milk of a given cow and the Staph. aureus load in milk from a cow milked subsequently with the same milking unit/milk meter (higher risk with increasing Staph. aureus exposure). Carryover affected the PCR results for Staph. aureus in composite milk samples taken at milk recording. Three categories seem to be useful for practical purposes: (A) very likely to be infected with Staph. aureus (Ct-value $<32$ ), very likely to be negative for Staph. aureus (Ct-value $>37$ ), and (C) uncertain Staph. aureus status (Ct-value 32-37). Cows in category A are very unlikely to be affected by carryover, but bacterial DNA concentration in the milk samples of cows in this group can affect the results of uninfected cows milked subsequently. Cows in categories B and C are likely to be affected by carryover from the antecedent cows, leading to misclassification of IMI with Staph. aureus. Further diagnostic information is necessary to evaluate the status of cows in category $\mathrm{C}$, either by considering the milking order or including PCR Ct-values from previously milked cows, retests, or other information on infectious status.

\section{ACKNOWLEDGMENTS}

The authors gratefully acknowledge the staff of Eurofins Steins Laboratory for providing us with the laboratory space to conduct this research and for their technical and logistic support. We also thank the Knowledge Center for Agriculture, Cattle, for funding the PCR testing. Thanks to the Danish farmers for their help and in making their cows available for our study. Yasser Mahmmod was supported by the Islamic Development Bank Merit Scholarship Program (IDB-MSP), Jeddah, Saudi Arabia, scholarship number (600031332).

\section{REFERENCES}

Barkema, H. W., Y. H. Schukken, and R. N. Zadoks. 2006. Invited review: The role of cow, pathogen, and treatment regimen in the therapeutic success of bovine Staphylococcus aureus mastitis. J. Dairy Sci. 89:1877-1895.

Boss, R., A. Cosandey, M. Luini, K. Artursson, M. Bardiau, F. Breitenwieser, E. Hehenberger, T. Lam, M. Mansfeld, A. Michel, G. Mösslacher, J. Naskova, S. Nelson, O. Podpečan, A. Raemy, E. Ryan, O. Salat, P. Zangerl, A. Steiner, and H. U. Graber. 2016. Bovine Staphylococcus aureus: Subtyping, evolution, and zoonotic transfer. J. Dairy Sci. 99:515-528.

Britten, A. M. 2012. The role of diagnostic microbiology in mastitis control programs. Vet. Clin. North Am. Food Anim. Pract. 28:187-202.

Byrem, T. M., B. D. Voisinet, and S. J. Sievert. 2013. Milk Recording Samples-Multiple Analyses, Multiple Challenges. ICAR Technical Meeting. ICAR, Aarhus, Denmark.

Cederlöf, S. E., N. Toft, B. Aalbaek, and I. C. Klaas. 2012. Latent class analysis of the diagnostic characteristics of PCR and conventional bacteriological culture in diagnosing intramammary infections caused by Staphylococcus aureus in dairy cows at dry off. Acta Vet. Scand. 54:65.

Dufour, S., I. R. Dohoo, H. W. Barkema, L. Descôteaux, T. J. Devries, K. K. Reyher, J. P. Roy, and D. T. Scholl. 2012. Manageable risk factors associated with the lactational incidence, elimination, and prevalence of Staphylococcus aureus intramammary infections in dairy cows. J. Dairy Sci. 95:1283-1300.

Friendship, C., D. Kelton, D. V. Water, D. Slavic, and M. Koskinen. 2010. Field evaluation of the Pathoproof mastitis PCR assay for the detection of Staphloccoccus aureus infected cows using DHI samples. Pages 226-227 in NMC 49th Ann. Mtg. Proc., Albuquerque, NM. Natl. Mastitis Counc., Inc., New Prague, MN.

Friggens, N. C., and M. D. Rasmussen. 2002. Milk quality assessment in automatic milking systems: Accounting for the effects of vari- 
able intervals between milkings on milk composition. Livest. Prod. Sci. $73: 45-54$.

Hiitiö, H., R. Riva, T. Autio, T. Pohjanvirta, J. Holopainen, S. Pyörälä, and S. Pelkonen. 2015. Performance of a real-time PCR assay in routine bovine mastitis diagnostics compared with indepth conventional culture. J. Dairy Res. 82:200-208.

Hiitiö, H., H. Simojoki, P. Kalmus, J. Holopainen, S. Pyörälä, and S. Taponen. 2016. The effect of sampling technique on PCRbased bacteriological results of bovine milk samples. J. Dairy Sci. 99:6532-6541.

Katholm, J., T. W. Bennedsgaard, M. T. Koskinen, and E. Rattenborg. 2012. Quality of bulk tank milk samples from Danish dairy herds based on real-time polymerase chain reaction identification of mastitis pathogens. J. Dairy Sci. 95:5702-5708.

Keane, O. M., K. E. Budd, J. Flynn, and F. McCoy. 2013. Increased detection of mastitis pathogens by real-time PCR compared to bacterial culture. Vet. Rec. 173:268.

Keefe, G. 2012. Update on control of Staphylococcus aureus and Streptococcus agalactiae for management of mastitis. Vet. Clin. North Am. Food Anim. Pract. 28:203-216.

Kelton, D. F., and M. A. Godkin. 2014. Frequently asked questions about the Pathoproof mastitis 3 PCR assay. Pages 127-132 in NMC 53rd Ann. Mtg. Proc., Fort Worth, TX. Natl. Mastitis Counc. Inc., New Prague, MN.

Koskinen, M. T., J. Holopainen, S. Pyorala, P. Bredbacka, A. Pitkala, H. W. Barkema, R. Bexiga, J. Roberson, L. Solverod, R. Piccinini, D. Kelton, H. Lehmusto, S. Niskala, and L. Salmikivi. 2009. Analytical specificity and sensitivity of a real-time PCR assay for identification of bovine mastitis pathogens. J. Dairy Sci. 92:952-959.

Koskinen, M. T., J. Holopainen, L. Salmikivi, H. Lehmusto, S. Niskala, and J. Kurkela. 2008. Analytic detection limit of the PathoProof Mastitis PCR assay determined using two different experimental approaches. Pages 183-189 in Mastitis Control-From Science to Practice. Wageningen Academic Publishers, Wageningen, the Netherlands.

Koskinen, M. T., G. J. Wellenberg, O. C. Sampimon, J. Holopainen, A. Rothkamp, L. Salmikivi, W. A. van Haeringen, T. J. Lam, and S. Pyörälä. 2010. Field comparison of real-time polymerase chain reaction and bacterial culture for identification of bovine mastitis bacteria. J. Dairy Sci. 93:5707-5715.

Larsen, H. D., K. H. Sloth, C. Elsberg, C. Enevoldsen, L. H. Pedersen, N. H. R. Eriksen, F. M. Aarestrup, and N. E. Jensen. 2000. The dynamics of Staphylococcus aureus intramammary infection in nine Danish dairy herds. Vet. Microbiol. 71:89-101.

Lind, A., P. T. Thomsen, A. K. Ersbøll, M. N. Espetvedt, C. Wolff, S. Rintakoski, and H. Houe. 2012. Validation of Nordic dairy cattle disease recording databases - Completeness for locomotor disorders. Prev. Vet. Med. 107:204-213.
Løvendahl, P., M. Bjerring, and T. Larsen. 2010. Determination of carry-over in automated milking, recording and sampling systems using fluorescent tracers. Pages 147-152 in Proc. ICAR 37th Ann. Mtg., Riga, Latvia. ICAR, Rome, Italy.

Løvendahl, P., and M. A. Bjerring. 2006. Detection of carryover in automated milk sampling equipment. J. Dairy Sci. 89:3645-3652.

Mahmmod, Y. S., I. C. Klaas, S. S. Nielsen, J. Katholm, and N. Toft 2013b. Effect of presampling procedures on real-time PCR used for diagnosis of intramammary infections with Staphylococcus aureus in dairy cows at routine milk recordings. J. Dairy Sci. 96:22262233.

Mahmmod, Y. S., M. M. Mweu, S. S. Nielsen, J. Katholm, and I. C. Klaas. 2014. Effect of carryover and presampling procedures on the results of real-time PCR used for diagnosis of bovine intramammary infections with Streptococcus agalactiae at routine milk recordings. Prev. Vet. Med. 113:512-521.

Mahmmod, Y. S., N. Toft, J. Katholm, C. Grønbæk, and I. C. Klaas. 2013a. Bayesian estimation of test characteristics of real-time PCR, bacteriological culture and California mastitis test for diagnosis of intramammary infections with Staphylococcus aureus in dairy cattle at routine milk recordings. Prev. Vet. Med. 112:309-317.

Nekouei, O. A., J. Sanchez, and G. P. Keefe. 2015. Carryover of bovine leukemia virus antibodies in samples from shared milk meters. J. Dairy Sci. 98:5274-5279.

Sievert, S. J., and R. J. Cantin. 2014. Best practices to minimize carryover contamination in milk recording samples, both from operator and from equipment design and set-up perspectives. ICAR Technical Meeting, Berlin, Germany. ICAR, Rome, Italy.

Sørensen, L. P., T. Mark, M. K. Sørensen, and S. Ostergaard. 2010. Economic values and expected effect of selection index for pathogen-specific mastitis under Danish conditions. J. Dairy Sci. 93:358-369.

Steele, N. M., J. H. Williamson, R. A. Laven, and J. E. Hillerton. 2015. Using polymerase chain reaction to identify Streptococcus uberis in bovine milk: How does it compare with bacterial culture? Proc. N.Z. Soc. Anim. Prod. 75:20-23.

Taponen, S., L. Salmikivi, H. Simojoki, M. T. Koskinen, and S. Pyörälä. 2009. Real-time polymerase chain reaction-based identification of bacteria in milk samples from bovine clinical mastitis with no growth in conventional culturing. J. Dairy Sci. 92:26102617.

Walsh, R. B., D. F. Kelton, S. K. Hietala, and T. F. Duffield. 2013. Evaluation of enzyme-linked immunosorbent assays performed on milk and serum samples for detection of neosporosis and leucosis in lactating dairy cows. Can. Vet. J. 54:347-352.

Zecconi, A. 2006. Can we eradicate Staphylococcus aureus mastitis? Accessed Dec. 19, 2016. http://www.ivis.org/proceedings/wbc/ wbc2006/zecconi.pdf. 